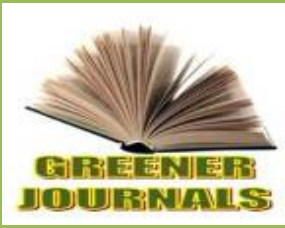

\title{
Determinants of Access to Formal Credit by Smallholder Tobacco Farmers in Makoni District, Zimbabwe
}

\section{Lighton Dube $^{1 *}$, Tatenda Mariga ${ }^{2}$ and May Mrema ${ }^{2}$}

${ }^{1}$ Faculty of Commerce and Law, Zimbabwe Open University, National Office, P.O Box MP 111, Mt Pleasant, Harare, Zimbabwe

${ }^{2}$ Faculty of Agriculture and Natural Resources, Africa University, P. O. Box 1320, Mutare, Zimbabwe

ARTICLE INFO

Article No.: 011515003

DOI: 10.15580/GJAS.2015.1.011515003

Submitted: 02/01/2015

Accepted: $21 / 01 / 2015$

Published: 05/02/2015

${ }^{*}$ Corresponding Author

Lighton Dube

E-mail:dubelig@gmail.com

Keywords:

Smallholder tobacco farmers, formal credit, Makoni district, logit model
This study used data from 77 smallholder tobacco farmers from Makoni district in Zimbabwe to investigate factors affecting smallholder tobacco farmers' access to formal credit. The results of the study showed that contact with extension services, farmer's attitude towards risk of borrowing and ownership of land cultivated significantly and positively influenced the probability of farmers' access to formal credit in the study area. These findings confirm that improving access to extension services and secure land ownership remain the important factors in the quest to improving access of smallholder farmers to formal credit in Zimbabwe. Improved access to information on credit use through extension services is also likely to positively influence farmers' perceptions on credit risk, which would in turn reduce fears associated with formal credit sources. Encouraging farmers to insure both their crop and loans against the event of crop failure can also be used to reduce the risk associated with formal credit sources and help improve access to formal credit by a majority of smallholder farmers. 


\section{INTRODUCTION}

Access to formal credit by smallholder farmers is one of the key drivers of economic development, which can help break the vicious circle of poverty in most agriculture based developing economies. Zimbabwe in recent years, has witnessed increased calls for greater development and efficiency of financial systems which are vital in allocating credit to farming households. Governments the world over frequently strive to provide cheap credit to the agricultural sector through subsidies and policies such as reducing the interest rate on borrowing. According to Delgado (1995) and Zeller et. al. (1997), easing potential capital constraints through the granting of credit reduces the opportunity costs of capital-intensive assets relative to family labor. This then encourages the adoption of labor-saving, higher-yielding technologies which in turn increases land and labor productivity, which is crucial in encouraging development.

Access to credit affects households' welfare through three different pathways (Zeller et. al., 1997). The first pathway is through the alleviation of the capital constraints on agricultural households. For agricultural households, expenditures on agricultural inputs, food and essential non-food items are incurred during the planting and vegetative growth periods of crops, whereas returns are received only after the crops are harvested several months later. As a result, most households show a negative cash flow during the growing season and credit access therefore can drastically raise the capability of households with no or few savings to meet their financial needs for agricultural inputs and productive investments. The second pathway is through increasing a household's risk-bearing ability and through altering its risk-coping strategy. Carter (1984) and Rosenzweig and Binswanger (1993) as cited by Tang et. al. (2010) established that access to credit could also increase rural poor households' willingness to adopt new technologies that raise both mean levels and reduce riskiness of income. The third pathway is through enabling access to credit for consumption smoothing. This together with the second pathway affect the resilience of households in bearing production and consumption risks (Diagne and Zeller, 2001).

Abdhalla and Ebaidalla (2012) note that agricultural finance is a decisive factor input in farming operations as it helps poor farmers to maintain consumption of basic necessities, adopt advanced technology and raise their incomes. Access to credit is therefore seen as a vital tool to enhance agricultural productivity, to encourage economic development and thereby alleviating poverty. Zeller and Sharma (1998) also view the provision of credit to rural population as a very effective strategy for poverty reduction. Komicha and Öhlmer Bo (2007) also found that credit constraint not only affects the purchasing power of farmers to procure farm inputs and cover operating costs in the short run, but also their capacity to make farm-related investments as well as risk behaviour in technology choice and adoption. These, in turn, have influence on the technical efficiency of the farmers which is critical in addressing smallholder productivity.

However despite all the potential positive contribution of agriculture finance to economic development and poverty reduction, the major problem with credit amongst formal institutions is that it is not easily available to farmers due to the institutions lending policies which make access difficult through complicated application procedures and credit restrictions. In Zimbabwe, in particular, lack of collateral, high interest rates, liquidity problem and lack of insurance which can be used as a guarantee, have been cited as the major challenges facing Zimbabwean smallholder farmers in accessing formal credit (Zimbabwe Farmers Union, 2011). The Zimbabwe Tobacco Association (2011) also noted that most financial institutions in Zimbabwe had no viable funding available to agriculture let alone to the tobacco sub-sector.

This study aims at identifying the determinants of access to formal credit by smallholder tobacco farmers in Makoni district of Zimbabwe. The study also aims to provide policy recommendations to the decision makers for taking appropriate actions towards increasing access to formal credit by smallholder tobacco farmers in Zimbabwe.

\section{LITERATURE REVIEW}

\section{Empirical Studies on Determinants of Access to Credit}

A number of factors explain why households' access to credit is sometimes limited. Doan et. al. (2010) found that married household heads tend to avoid informal credit, whereas the better communicating households borrow more from formal credit lenders. On the other hand, Hussien (2007) indicated that farm households are more likely to prefer the informal sector to the formal sector with respect to flexibility in rescheduling loan repayments in times of unexpected income shocks.

Doan et. al. (2010) found that the likelihood of credit constraints increases with distance to the nearest banks, which suggests that supply-side interventions could help in overcoming credit constraints. Okurut (2001) also found that the location of the financial service providers and their conditions greatly influence the probability of access. Komicha (2007) found that farm households are discouraged to borrow from the credit sector if it is located farther away. This is due to the monetary costs of transaction incurred, especially transportation cost, which increase with lender-borrower distance and in turn raises the effective cost of borrowing at otherwise relatively lower interest rate in the sector. Sarap (2000) suggests that high transaction 
costs do not only increase the effective interest rate but also deter potential small borrowers from approaching financial institutions for credit. Sarap (2000) went on to suggest that policies should be directed both towards reducing the overall transaction costs of formal loans to small farmers, and towards improved collection processes.

Amjad and Hasnu (2007) found the tenure status, family labor, literacy status, off-farm income, value of non-fixed assets and infrastructure quality to be the most important variables in determining access to formal credit. They also found that the total operated area, family labor, literacy status and off-farm income are significantly related to the determination of credit status of smallholder farmers from informal sources. Land tenure status was found to be the single most important variable determining credit status. On the other hand, Oboh and Ekpebu (2010) found that farmer's age, educational level, farm size and household size, length of loan delay and visitation by bank officials significantly affected the rate of credit allocation to farmers.

Duy $(2011,2012)$ in a study in Vietnam, found that access to credit was positively related to a larger family with relatively more dependants and that households with larger landholding had a higher probability of borrowing. The study also found that personal characteristics such as level of education, marital status and involvement in village work were important factors. Higher educated household heads, and those involved in village work borrowed larger sums.

Abdalla and Ebiadalla (2012) found that access of farmer to the formal credit institution is positively influenced by family size; experience of the household head in credit use; ownership of adequate collateral; and participation of the household head in training/extension activities. They also found that age of household head; distance travelled by farmer to the lending institution; farm size; number of the household males who are less than 17 years old-all these negatively affect the access to formal credit institutions. Large households had better chances to access formal credit, because it is expected that it has more earning members fulfilling a collateral requirements.

\section{RESEARCH METHODOLOGY}

\section{Study Area}

This study was conducted in Makoni district of Manicaland province. Makoni district is located in northeastern Zimbabwe. It is primarily a farming district and the chief cash crop is tobacco.

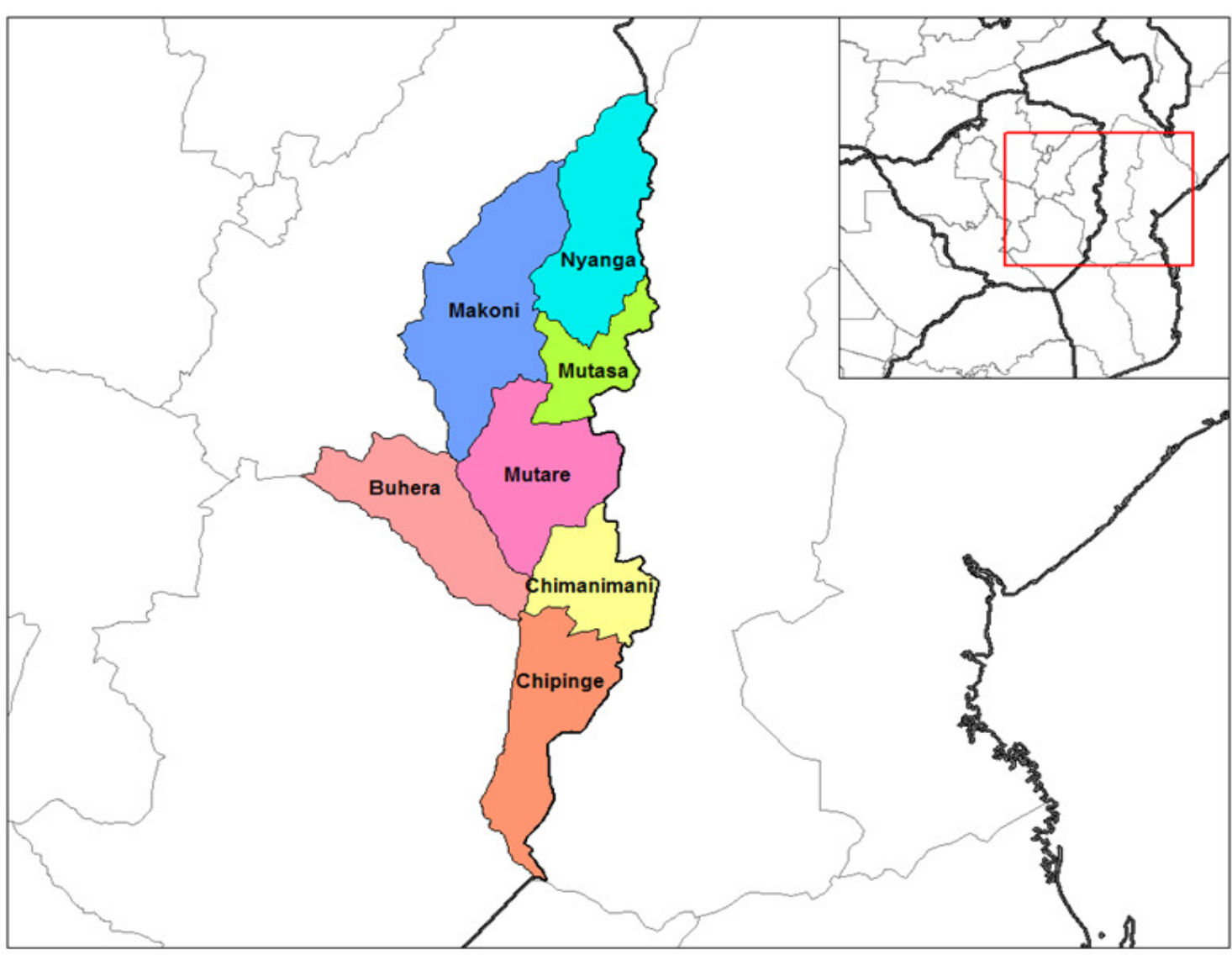

Figure 1: Map of Manicaland Province showing Makoni District 


\section{Data Collection and Analysis}

Data were collected using a pre-tested structured questionnaire from a random sample of 77 farmers in November 2012. Data were analyzed using descriptive statistics and inferential statistics. The descriptive statistics used were frequency counts, percentages and means, while the inferential statistical tool used was the logit regression model. The logit model is the recommended method for understanding the association between explanatory variables and a binary dependent variable (Greene, 2008; Hosmer and Limeshow, 2000; Long and Freese, 2006). Since the access to formal credit by tobacco farmers is a dichotomous or binary dependent variable, with the option of access to formal credit or no access to formal credit, the binary logistic regression model was applied. The logistic regression model explores the socio-economic factors influencing the access to formal credit by tobacco farmers. Accordingly, access to formal credit in the study area is influenced by a set of independent variables and it is specified as follows:

$$
Y_{i} / 1-Y_{i}=\beta_{0}+\beta_{1} X_{1 i}+\beta_{2} X_{2 i}+\beta_{3} X_{3 i}+\ldots \ldots \beta_{k} X_{k i}+\mu_{i}
$$

Where the subscript $i$ means the ith observation in the sample. $Y$ is the probability that a household has access to formal credit and $(1-Y)$ is the probability that a household does not have access to formal credit. $\beta_{0}$ is the intercept term and $\beta_{1}, \beta_{2}, \beta_{3}, \ldots . \beta_{k}$ are the coefficients of the independent variables $X_{1}, X_{2}, X_{3}$, ....... $\mathrm{X}_{\mathrm{k}}$.

In the analysis of the hypothesis of this study, access to formal credit (ACREDIT) was considered in relation to nine socio-economic explanatory variables; namely age of household head (AGE), sex of household head (SEX), family labour (FAMLAB), extension services contact (EXTCONT), experience in credit use from formal sources (EXPCRED), area cultivated (AREACULT), land ownership (LANDOWN), total livestock owned (LIVOWN) and attitude towards risk of accessing credit (RISKTAK). The determinant variables were defined as follows:

Age of household head (AGE): It is a continuous variable, measured in years. It is defined as the age of the head of household.

Sex of household head (SEX): This is a dummy variable that assumes a value of " 1 " if the head of the household is male and " 0 " otherwise. According to Fletschner and Kenney (2011), rural women's access to financial resources is limited by biased lending practices that consider them smaller, less experienced and therefore less attractive clients.

Family labour (FAMLAB): This refers to the total number of family members with the potential of working on the farm and was measured in man equivalent. The larger the number of family labour available, the more labour force available for production. The more the labour force available means less costs required for hired labour hence credit demand decreases. Therefore, family labor was hypothesized to have negative impact on access to credit.

Extension contact (EXTCONT): This refers to the number in days of contact with an extension officer that the household had within the year. Households with frequent extension contact are expected to have better knowledge and more information on credit use that will increase the demand for formal credit. It was therefore hypothesized that this variable positively influences farmer's access to use formal credit.

Experience in credit use from formal sources (EXPCRED): This refers to the number in years that a farmer has used credit from a formal credit institution. A household with more experience in formal credit use will have a higher tendency towards using the formal credit sources. This variable is assumed to have a positive influence on the dependant variable (Hossain, 1988, Zeller, 1994 and Yehuala, 2008).

Area cultivated (AREACULT): This refers to the total land size cultivated by the household and it is measured in hectares (ha). It is a continuous variable and it's expected that the larger the land cultivated, the more labour required which demands more capital which can be raised through access to credit (Yehuala, 2008, Amjad and Hasnu, 2007).

Land ownership (LANDOWN): This refers to whether a farmer is using his/her own land for tobacco production or is renting land from other farmers for the purpose of producing tobacco. This is a dummy variable that assumes a value of " 1 " if farmer is producing tobacco using own land and " 0 " otherwise. It is hypothesized that farmers who produce tobacco on own land have better chances of accessing formal credit than farmers who farm on rented land (Mohieldin and Wright, 1994).

Total livestock owned (LIVOWN): This is the total number of livestock owned by the household. Livestock is considered as an asset that can be liquidated or used as security in the case of crop failure. A household with a higher number of livestock is considered wealthier and has a higher income base and has more money available. Such a household would therefore be less likely to go for credit hence this variable was assumed to have a negative influence on a farmers access to credit (Yehuala, 2008).

Attitude towards risk of accessing credit (RISKTAK): A farmers' attitude towards risk is another factor that will affect whether a farmer will access credit or not. Farmers 
who view credit as very risky will not take it up even when available; however some view it as risky but will still take up the credit facility if available. Those that do not take up credit due to the risk factor do so due to fear of seasonal changes or crop failure. This factor will be measured based on the farmer's positive or negative perception. This is a dummy variable which takes "1" if they respond as they don't fear risk to take loans and " 0 " otherwise. Therefore, it was expected that farmers who are risk averse will not demand credit and it negatively affects access to use credit from the formal credit institutions.

\section{RESULTS AND DISCUSSION}

From the sampled households, 31 households had access to formal credit while the remainder had no access. The average age of the household heads was
44.9 years. The minimum and maximum ages were 26 and 77 years respectively. The average age of farmers with access to formal credit was 47.7 years and for farmers with no access to formal credit was 43.1 years. Household heads with a higher average age are expected to have more experience and exposure to farming and credit use, which in turn increases their access to credit.

The sample consisted of $85.7 \%$ of male headed households and $14.3 \%$ of female headed households (Table 1). This portrays the general ownership of farms by sex in Africa, where most households are headed by male farmers. The numbers of female headed households that had access to formal credit was less than that of male headed households. The implication is that male headed households have more access to formal credit as compared to the female headed households.

Table 1: Gender status by credit access group

\begin{tabular}{|l|l|l|l|l|l|l|}
\hline \multirow{2}{*}{ Gender Status } & \multicolumn{2}{l|}{$\begin{array}{l}\text { Farmers with access to } \\
\text { formal credit }(\mathrm{N}=31)\end{array}$} & \multicolumn{2}{l|}{$\begin{array}{l}\text { Farmers with no access to } \\
\text { formal credit (N=46) }\end{array}$} & \multicolumn{2}{l|}{ Total $(\mathrm{N}=77)$} \\
\cline { 2 - 7 } & $\mathrm{N}$ & $\%$ & $\mathrm{~N}$ & $\%$ & $\mathrm{~N}$ & $\%$ \\
\hline Female & 3 & 9.7 & 8 & 17.4 & 11 & 14.3 \\
\hline Male & 28 & 90.3 & 38 & 82.6 & 66 & 85.7 \\
\hline
\end{tabular}

Source: Survey Data, 2012

The average family size of the respondents' households was found to be 4 persons. The largest family size was 7 and the smallest was 1 . From the total sampled household, $58.1 \%$ of farmers with access to formal credit had a family size of $4-6$ people and $60.9 \%$ of farmers with no access to formal credit had a family size of $1-3$ people (Table 2).

Table 2: Household size by credit access group

\begin{tabular}{|l|l|l|l|l|l|l|}
\hline \multirow{3}{*}{ Household Size } & \multicolumn{2}{l|}{$\begin{array}{l}\text { Farmers with access to } \\
\text { formal credit }(\mathrm{N}=31)\end{array}$} & \multicolumn{2}{l|}{$\begin{array}{l}\text { Farmers with no access to } \\
\text { formal credit (N=46) }\end{array}$} & \multicolumn{2}{l|}{ Total $(\mathrm{N}=77)$} \\
\cline { 2 - 7 } & $\mathrm{N}$ & $\%$ & $\mathrm{~N}$ & $\%$ & $\mathrm{~N}$ & $\%$ \\
\hline $1-3$ & 9 & 29.0 & 28 & 60.9 & 37 & 48.1 \\
\hline $4-6$ & 18 & 58.1 & 18 & 39.1 & 36 & 46.7 \\
\hline$>6$ & 4 & 12.9 & 0 & 0 & 4 & 5.2 \\
\hline
\end{tabular}

Source: Survey Data, 2012

The average number of children for farmers with access to formal credit was 4.5 while that of farmers with no access was 3.4. The mean family labour available for farmers with access to formal credit and for those with no access to formal credit was 3.3 and 2.8 man-days respectively. The mean family labour is lower than the average number of children for both categories of farmers because some of the children are still young to provide family labour. The average family labour available for female and male headed households was 4.35 and 3.8 man-days respectively.

About $64.5 \%$ of farmers with access to formal credit reported that the available family labour was insufficient for effective production and therefore have to source out labour from elsewhere when it is necessary. The remainder, $35.5 \%$ of the farmers with access to formal credit reported that the available family labour was sufficient. These figures show that labour is in short supply to the majority of the farmers in the study area. Labour shortage increases the demand for hired labor, which increases operating expenses to farmers and in turn also increases the need for credit. The survey results also indicated that $30.4 \%$ and $69.6 \%$ of the farmers with no access to formal credit had insufficient and sufficient family labour respectively.

The ratio of the dependant family members to economically active members was 0.44. Dependant family members in this study are defined as children under the age of 13 , disabled persons and adults older than 64 years. Dependant family members affect sufficiency because dependants are not expected to work on the farm as labour.

The results also show that $83.1 \%$ of the respondents had extension contact, while $16.9 \%$ did not have contact with any extension agents. The average number of extension contact days for farmers with 
access to formal credit and for farmers with no access to formal credit was 5.16 and 2.34 days per year respectively. Farmers with access to formal credit had more extension contact days than those with no access and were therefore more exposed to farming and credit use information through the extension agents. The average extension contact days for female headed households and male headed households were 0.72 days and 2.45 days per annum. On the other hand, from all the sampled respondents $54.5 \%$ of female headed households and $84.8 \%$ of male headed households were provided extension services from the extension agents although the extent of the contact is small.

The number of years experience in credit use varied amongst the sampled households with $70.1 \%$ of the sampled households having experience in credit use. The average number of years of credit experience for all sampled households was 1.7 years. Farmers with access to formal credit had an average experience in credit use of 1.9 years and those with no access to formal credit had an average experience of 1.1 years. The lower level of experience in credit use by farmers with no access to formal credit could possibly limit their access to formal credit facilities as most financial institutions check the production history of the farmers.

With regards to the literacy level, $81.8 \%$ of the sampled households were literate while $18.2 \%$ were illiterate (Table 3 ). Ninety percent of the farmers with access to formal credit were literate while $76 \%$ of the farmers with no access to formal credit were literate. This may probably mean that literate farmers have more exposure to the external environment and information which helps them easily associate to credit sources and hence gain access to credit.

Table 3: Literacy status by credit access group

\begin{tabular}{|l|l|l|l|l|l|l|l|}
\hline \multirow{2}{*}{ Literacy status } & \multicolumn{2}{|l|}{$\begin{array}{l}\text { Farmers with access to } \\
\text { formal credit }(\mathrm{N}=31)\end{array}$} & \multicolumn{2}{l}{$\begin{array}{l}\text { Farmers with no access to } \\
\text { formal credit }(\mathrm{N}=46)\end{array}$} & \multicolumn{2}{l|}{ Total $(\mathrm{N}=77)$} \\
\cline { 2 - 7 } & $\mathrm{N}$ & $\%$ & $\mathrm{~N}$ & $\%$ & $\mathrm{~N}$ & $\%$ \\
\hline Literate & 28 & 90.3 & 35 & 76.1 & 63 & 81.8 \\
\hline Illiterate & 3 & 9.7 & 11 & 23.9 & 14 & 18.2 \\
\hline
\end{tabular}

Source: Survey Data, 2012

Almost sixty-five percent of farmers with access to formal credit are cultivating 4-7 hectares compared to just 24 percent of farmers with no access to formal credit (Table 4). Only seven percent of farmers with access to formal credit are cultivating less than 4 hectares compared to 46 percent of the farmers with no access to formal credit.

Table 4: Area cultivated status by credit access group

\begin{tabular}{|l|l|l|l|l|l|l|l|}
\hline $\begin{array}{l}\text { Area } \\
\text { (ha) }\end{array}$ & cultivated & $\begin{array}{l}\text { Farmers with access to } \\
\text { formal credit }(\mathrm{N}=31)\end{array}$ & $\begin{array}{l}\text { Farmers with no access to } \\
\text { formal credit }(\mathrm{N}=46)\end{array}$ & \multicolumn{2}{|l|}{ Total $(\mathrm{N}=77)$} \\
\cline { 2 - 8 } & $\mathrm{N}$ & $\%$ & $\mathrm{~N}$ & $\%$ & $\mathrm{~N}$ & $\%$ \\
\hline$<4$ & 2 & 6.5 & 21 & 45.7 & 23 & 29.9 \\
\hline $4-7$ & 20 & 64.5 & 11 & 23.9 & 31 & 40.2 \\
\hline$>7$ & 9 & 29.0 & 14 & 30.4 & 23 & 29.9 \\
\hline
\end{tabular}

Source: Survey Data, 2012

Most farmers undertake both crop and livestock production activities, with $86.4 \%$ of the sampled respondents owning livestock. The livestock produced by the farmers is used either as food for the household or is sold to provide income for the household which can be used to purchase inputs for farming or used for basic consumption in the family. Some livestock like the donkeys are used as transport in which they pull trailers of tobacco to barns or to the main road for public transportation to the auction floors. The mean number of livestock holding amongst the sampled households was 4.1 and the farmers with access to formal credit possessed relatively more livestock than those with no access to formal credit (Table 5).

Table 5: Livestock holding by credit user group

\begin{tabular}{|l|l|l|l|}
\hline Livestock Type & $\begin{array}{l}\text { Farmers with access to } \\
\text { formal credit }(\mathrm{N}=31)\end{array}$ & $\begin{array}{l}\text { Farmers with no access } \\
\text { to formal credit }(\mathrm{N}=46)\end{array}$ & Mean Total \\
\hline Cattle & 4.2 & 2.3 & 3.8 \\
\hline Donkeys & 0.9 & 1.3 & 1.1 \\
\hline Goats & 2.4 & 4.1 & 3.6 \\
\hline Chickens & 5.1 & 4.8 & 5.0 \\
\hline Mean Total Livestock & 4.3 & 3.9 & 4.1 \\
\hline
\end{tabular}


The study also assessed the attitudes of the farmers towards risk associated with formal credit. About $52 \%$ of the total sampled households indicated that they do not want to take the risk of borrowing from formal financial institutions (Table 6). Amongst the farmers with access to formal credit, $35.5 \%$ indicated that it was risky borrowing from formal financial sources while $63 \%$ of the farmers with no access to formal credit indicated that borrowing from formal financial sources was risky and feared taking the risk that comes with borrowing.
The results also showed that male and female headed households have different perceptions on the risk associated with borrowing. Ninety-one percent of the female headed households and $29 \%$ of the male headed households thought borrowing was risky. The result indicates that the majority of the female headed households fear the risk of repayment, while the majority of the male headed households have a different opinion. This difference in opinions may be one of the problems for lower participation of women in the formal credit market.

Table 6: Household opinion on credit risk and lending procedures

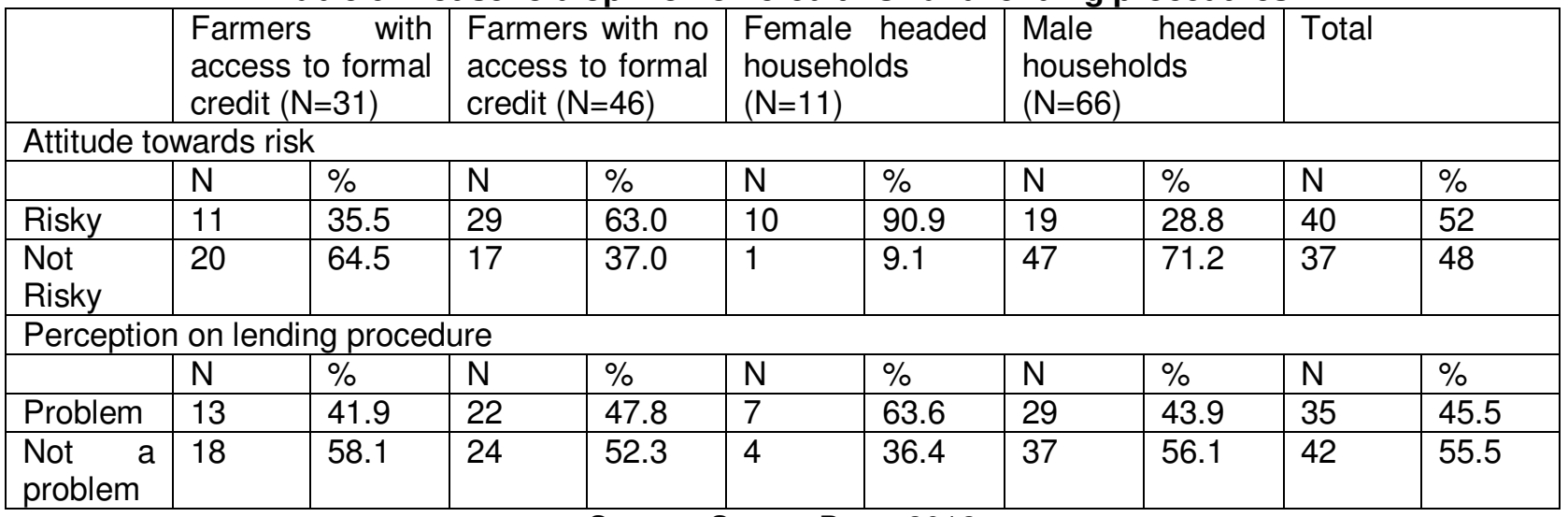

Source: Survey Data, 2012

Farmers were also asked to give their opinion on the lending procedures used by formal credit sources. Fiftyfive percent of the households indicated that the lending procedures were not a problem (Table 6). Fifty-eight percent of the farmers with access to formal credit and $52.2 \%$ of the farmers with no access to formal credit indicated that the lending procedures were not a problem. The majority of the credit users and the non users thought that the lending procedure was not a problem because most sampled households get their loans from tobacco merchants who have simpler lending procedures and requirements when compared to those of formal commercial banks.

On the other hand, $63.6 \%$ of the female headed households and $43.9 \%$ of the male headed households viewed the lending procedure as a problem. Hence, the result shows that women find the lending procedure more difficult as compared to man. This could be another reason for lack of women's participation in formal credit markets.

\section{Determinants of tobacco farm households access to formal credit}

The results of the logit regression model show that attitude towards risk (ATTRISK), extension contact days (EXTCONT) and land ownership (LANDOWN) were important factors influencing smallholder tobacco farmers access to formal credit in the study area (Table
7). The age of the head of household (AGE), sex of the head of household (SEX), area cultivated (AREACULT), experience in credit use (EXPCRED), family labour (FAMLAB) and livestock ownership (LIVOWN) do not significantly influence access to formal credit by smallholder tobacco farmers in the study area.

Contact with extension services significantly and positively influences smallholder tobacco farmers access to formal credit. The results show that on average, an increase of a farmer's contact with extension services by one day increases a farmer's probability of accessing formal credit by 0.06 . This is consistent with apriori expectations and findings of Abdalla and Ebaidalla (2012).

Land ownership (LANDOWN) was found to positively and significantly influence access to formal credit by smallholder tobacco farmers in the study area. On average, ownership of the cultivated tobacco land increases a farmer's probability of access to formal credit by 33 percent when compared to farmers who cultuivate rented farms. This result was consistent with a priori expectations and the findings of previous studies by Mohieldin and Wright (1994) and Amjad and Hasnu (2007).

Farmers attitude towards risk of borrowing (ATTRISK) was found to have a significant and positive effect on a farmers access to formal credit. A positive attitude towards risk of borrowing increases the probability of a farmer's access to formal credit by 30 
percent. This result is consistent with the findings of Miller and Ladman (1983).

Table 7: Results of Logistic Analysis on access to formal credit

\begin{tabular}{|c|c|c|c|c|}
\hline Variable & Coefficient & Std. Error & $t$ & Sig \\
\hline CONSTANT & -0.144 & 0.151 & -0.951 & 0.345 \\
\hline AGE & 0.004 & 0.003 & 1.529 & 0.131 \\
\hline SEX & -0.142 & 0.088 & -1.610 & 0.112 \\
\hline ATTRISK & 0.302 & 0.075 & 4.050 & 0.000 \\
\hline EXP & 0.009 & 0.024 & 0.381 & 0.705 \\
\hline EXTCONT & 0.060 & 0.012 & 5.177 & 0.000 \\
\hline FARMLAB & 0.007 & 0.018 & 0.361 & 0.719 \\
\hline FARMSIZE & 0.008 & 0.016 & 0.537 & 0.593 \\
\hline LANDOWN & 0.331 & 0.078 & 4.236 & 0.000 \\
\hline LIVEOWN & -0.018 & 0.012 & -1.578 & 0.119 \\
\hline \multicolumn{5}{|c|}{$\begin{array}{l}\text { Statistics: } \\
\text { No. of observations }=77 \\
F(9,67)=25.31 \\
\text { Prob }>F=0.0000 \\
R-\text { squared }=0.773 \\
\text { Adj. R-squared }=0.742\end{array}$} \\
\hline Dependent V & ACREDIT & & & \\
\hline
\end{tabular}

\section{CONCLUSION AND RECOMMENDATIONS}

This study investigates the determinants of access to formal credit by smallholder tobacco farmers of Makoni district in Zimbabwe. The findings indicate that contact with extension services, attitude towards risk of borrowing and ownership of cultivated land significantly and positively influences access to formal credit in the study area. Other socio-economic factors (the age of the head of household, sex of the head of household, area cultivated, experience in credit use, family labour and livestock ownership) do not significantly influence access to formal credit by smallholder tobacco farmers in the study area. The study recommends that there is need to improve access to extension services for tobacco farmers and also to provide extension related information to farmers as this increases the probability of access to formal credit. Provision of credit related information through extension services is also likely to change the risk attitude towards credit for those farmers who are not currently accessing formal credit. Those that do not take up credit due to the risk factor mainly do so due to fear of seasonal changes or crop failure. This fear of crop failure which results in farmers avoiding formal credit sources can be mitigated through encouraging farmers to ensure both their crop and loans against the event of crop failure.

\section{COMPETING INTEREST}

I declare that amongst all the three authors, there are no competing interests.

\section{AUTHOR CONTRIBUTION}

All the three authors contributed equally in the production of this manuscript.

\section{REFERENCES}

Abdalla, E. M. and Ebaidalla, E. M. (2012). Determinants of small farmer's access to formal credit institutions in Kassala state, East Sudan. University of Kassala Journal, First Issue, April 2012.

Amjad. S and Hasnu SAF (2007). Smallholders' access to rural credit: Evidence from Pakistan. The Labore Journal of economics. Vol. 12(2): 1-25

Binswanger, H., Khandker, S. and Rosenzweig, M. (1989). How infrastructure and financial institutions affect agricultural output and investment in India. World Bank, Washington D. C. World Bank Working Paper No. 163.

Delgado, C. L. (1995). Africa's changing agricultural development strategies: Past and present paradigms as a guide to the future. International Food Policy Research Institution, Washington D. C. Agriculture, and the Environment Discussion Paper 3.

Diagne, A. (1999). Determinants of households' access to and participation in formal and informal credit market in Malawi. International Food Policy Research Institution, Washington D. C. FCND Discussion Paper No. 67

Diagne, A. and Zeller, M. (2001). Access to credit and its impact on welfare in Malawi. International Food Policy Research Institute, Washington D. C. Research report 116 
Doan, T., Gibson, J. and Holmes, M. (2010). What determines credit participation and credit constraints of the poor in peri-urban areas, Vietnam? MPRA Paper No. 27509.

Duy, V. Q. (2011). Factors affecting on Access to formal credit of households in the Mekong delta, Vietnam. School of Economics and Business Administration, Can Tho University, Vietnam

Duy, V. Q. (2012). Determinants of household access to formal credit in the rural areas of the Mekong Delta, Vietnam. MPRA Paper No. 38202

Fletschner, D. and Kenney, L. (2011). Rural Women's Access to Financial Services Credit, Savings and Insurance. ESA working paper No. 11-07. The Food and Agriculture Organization of the United Nations, 2010-2011.

Greene, W.H. (2008). Econometric Analysis, $6^{\text {th }}$ Edition, Upper Saddle River, New Jersey, Prentice-Hall, New York University.

Hosmer, D.W., \& Lemeshow, S. (2000). Applied Logistic Regression. Second Edition. A Wiley-Inter science Publication. New York.

Hossain, M. (1988). Credit for the Alleviation of Rural Poverty: The Grameen Bank in Bangladesh. IFPRI Research Report No. 65.

Komicha, H. H. (2007). Farm Household Economic Behaviour in Imperfect Financial Markets: Empirical Evidence and Policy Implications on Saving, Credit and Production Efficiency in Southeastern Ethiopia. Doctoral Thesis, Swedish University of Agricultural Sciences, Uppsala.

Komicha, H. H. and Öhlmer, Bo (2007). Influence of Credit Constraint on Technical Efficiency of Farm Households in Southeastern Ethiopia. International Conference on African Development Archives. Paper 125.

http://scholarworks.wmich.edu/africancenter icad ar chive/125

Long, S.T., and Freese, J. (2006). Regression Model for Categorical Dependent Variables Using STATA. Texas: A Stata Press Publication, College Station.

Miller, C. J. and Ladman, J. R. (1983) Factors Impeding Credit Use in Small Farm Households in Bolivia. The Journal of Development Studies, 19(4): 523.
Mohieldin, S. and Wright, W. (2000). Formal and Informal Credit Markets in Egypt. Economic Research Forum, Working Paper No. 9415.

Oboh, V. U. and Ekpebu, I. D. (2010). Determinants of formal agricultural credit allocation to the farm sector by arable crop farmers in Benue State, Nigeria. African Journal of Agricultural Research, Vol. 6(1):181-185

Okurut, F. N. (2001). Access to Credit by the Poor in South Africa: Evidence from Household Survey Data 1995 and 2000. Stellenbosch Economic Working Papers: 13/06|

Sarap, K. (2000). Factors Affecting Small Farmers' Access to Institutional Credit in Rural Orissa, India. Development and Change, Vol. 21(2): 281-307

Tang, S., Guan, Z. and Jin, S. (2010). Formal and Informal Credit Markets and Rural Credit Demand in China. Paper presented at Agricultural \& Applied Economics Association 2010 AAEA,CAES, \& WAEA Joint Annual Meeting, Denver, Colorado, July 25-27, 2010

TIMB (2011). Reviewing the Industry for Sustainable Growth. TIMB National Tobacco Workshop Report:

Yehuala, S. (2008). Determinants of Smallholder Farmers Access to Formal Credit: The Case of Metema Woreda, North Gonder, Ethiopia. M.Sc. Thesis, Haramaya University, Ethiopia.

Zeller, M. (1994). Determinants of Credit Rationing: A Study of Informal Lenders and Formal Credit Groups in Madagascar. World Development, Vol. 22 No. 12: 1895 - 1907

Zeller, M. and Sharma, M. (1998). Rural Finance and Poverty Alleviation. Food Policy Report, IFPRI, Washington D.C.

Zeller, M., G. Schrieder, J. von Braun \& Heidhues, F. 1997. Rural Finance for Food Security for the Poor: Implications for Policy and Research. Food Policy Review No. 4. Washington, D.C.: International Food Policy Research Institute (IFPRI).

ZFU (2011). Experience Theme: Reviewing the Industry for Sustainable Growth. ZFU workshop report. 